\title{
Validity and reliability of a Hausa language questionnaire assessing information, motivation and Behavioural skills for malaria prevention during pregnancy
}

Ahmed Dahiru Balami i* Salmiah Md. Said², Nor'afiah Mohd Zulkefli², Norsa'adah Bachok ${ }^{3}$ and Bala Muhammad Audu ${ }^{4}$

\begin{abstract}
Background: Many studies on malaria knowledge, attitude and practice among pregnant women have been conducted in Hausa speaking communities in Nigeria. Despite this, no standard and uniform instrument for assessing this important public health problem has been developed in the Hausa language, even though it is widely spoken. The aim of this study was to develop and validate a questionnaire in Hausa language assessing information, motivation, and behavioural skills for malaria prevention during pregnancy.
\end{abstract}

Methods: The questionnaire was first developed in English language, and then assessed for its contents by a team of experts. It was then forwardly translated to Hausa, and backwardly translated again to English by independent language experts. These two English versions were then compared by a Public Health expert, following which the questionnaire was administered to 190 Hausa speaking antenatal care attendees. Exploratory factor analysis was performed on the data collected. Sixty three out of the 190 respondents were invited after 2 weeks to answer the same questionnaire, following which reliability tests were performed.

Results: The questionnaire showed good internal consistency, with Cronbach's alpha values of 0.859, 0.890 and 0.773 for information, motivation and behavioural skills constructs respectively. The motivation and behavioural skills constructs were able to delineate their items into three and two sub-sections respectively. The factor loadings for the two constructs ranged from 0.610 to 0.965 . As for test retest reliability, the Krippendorff's alpha values for the items of the motivation section ranged from 0.941 to 0.996 ; that for behavioural skills ranged from 0.810 to 0.953 , while for frequency of ITN use, it was 0.988. The Cohen's kappa values for the information section ranged from 0.689-0.974, except the item for 'fever' (zazzabi) which was 0.382 , and was as such reworded to a simpler terminology 'hotness of the body' (zafin jiki).

Conclusions: The Hausa language IMB questionnaire on malaria in pregnancy demonstrated good validity, and a high level of reliability. It is as such recommended for use among Hausa speaking communities to ensure uniformity and objectivity.

Keywords: Questionnaire, Hausa, Malaria in pregnancy, Information-motivation-behavioural skills, Validation

\footnotetext{
* Correspondence: ahdahiru@yahoo.com

'Department of Disease Control and Elimination, Medical Research Council

The Gambia at London School of Hygiene and Tropical Medicine, Fajara, The Gambia

Full list of author information is available at the end of the article
}

(c) The Author(s). 2020 Open Access This article is licensed under a Creative Commons Attribution 4.0 International License, which permits use, sharing, adaptation, distribution and reproduction in any medium or format, as long as you give appropriate credit to the original author(s) and the source, provide a link to the Creative Commons licence, and indicate if changes were made. The images or other third party material in this article are included in the article's Creative Commons licence, unless indicated otherwise in a credit line to the material. If material is not included in the article's Creative Commons licence and your intended use is not permitted by statutory regulation or exceeds the permitted use, you will need to obtain permission directly from the copyright holder. To view a copy of this licence, visit http://creativecommons.org/licenses/by/4.0/ The Creative Commons Public Domain Dedication waiver (http://creativecommons.org/publicdomain/zero/1.0/) applies to the data made available in this article, unless otherwise stated in a credit line to the data. 


\section{Background}

Malaria remains a public health problem in Nigeria, as it contributed the largest percent of cases $(27 \%)$ to its global incidence in the year 2016 [1]. Malaria had also been reported to account for $11 \%$ of maternal mortality [2]. Despite the World Health Organization's recommendations (WHO) for pregnant women in sub-Saharan Africa to always sleep under an insecticide-treated net (ITN) and take at least two doses of intermittent preventive treatment during their pregnancy (IPTp) [3], the level of compliance to these preventive measures has been very low among pregnant women in Nigeria [4]. Many studies have been conducted on knowledge, attitude and practice of pregnant women towards malaria, ITN, and IPTp, in Hausa speaking communities [5-11]. Hausa language is widely spoken not only in Nigeria, but also in many other African countries like Niger Republic, Ghana and Sudan, with an estimated 50 to 60 million people who understand the language to various degrees [12]. There exists the need to develop a valid uniform assessment tool in this widely spoken language, to enable uniform assessment by researchers, and facilitate the efficient monitoring of progress of public health interventions in that regard. Developing the instrument based on a health theory is likely to allow for a more thorough and systematic assessment of the health behaviour in question. The Protection Motivation Theory, while laying much emphasis on motivation, fails to identify other environmental and cognitive factors that can affect attitude change [13]. The informationmotivation-behaviourial skills (IMB) theory was first developed to explain HIV preventive behaviours among college students [14]. This theory comprises of three components which are information about the health behaviours, motivation to carry out such behaviours, and the requisite skills for performing such behaviours [14]. The aim of this study was to develop and validate a questionnaire in Hausa language assessing information, motivation, and behavioural skills for malaria prevention during pregnancy.

\section{Methods}

\section{Questionnaire development}

The questionnaire comprises of four sections which are the information, motivation, behavioural skills and behaviour sections. For the information section, its items were adapted from the knowledge sections of some previous studies $[6,11,15]$. Items of the motivation and behavioural skills sections were developed from modifications of the relevant sections of the IMB questionnaire on diabetes mellitus self-care by Osborn et al. [16]. The questionnaire was first developed in English language, after which it was translated through the process of translation and adaptation of instruments outlined by the WHO [17].

It was at first forwardly translated to Hausa language by a senior University academic staff of the Hausa Language Department. This translation was then assessed by a native
Hausa Public Health specialist, and then backwardly translated into English by a different translator of the same qualification. The two English versions (original and backtranslated) were then compared by another Public Health specialist. This was followed by questionnaire testing.

\section{Questionnaire structure \\ Section A}

This section had a total of 45 questions assessing the different domains of knowledge on malaria in pregnancy, which were: transmission, symptoms, complications, and prevention of malaria during pregnancy. There were three options for each question: 'Yes', 'No', and 'I don't know'. The total maximum obtainable information score was 45 points, while the minimum obtainable score was zero (0) points.

\section{Section B}

This section assessed participants' level of motivation for sleeping under an ITN and taking IPTp. It had a total of 12 items, and comprised of two sub-sections (one on personal motivation, and the other on social motivation). The first four items on personal motivation asked of the participants' perception of the level of goodness or otherwise of practicing those malaria preventive measures. These questions had response options on a five-point Likert scale thus: 'very bad', 'somewhat bad', 'neither bad nor good', 'somewhat good' and 'very good', which were scored $1,2,3$, 4, and 5 points respectively. The next four questions on personal motivation assessed participants' perception of the level of pleasantness or otherwise of practicing these preventive measures. These also had response options on a five-point Likert scale thus: 'very unpleasant', 'somewhat unpleasant', 'neither unpleasant nor pleasant', 'somewhat pleasant' and 'very pleasant', which were scored 1, 2, 3, 4, and 5 points respectively.

There were four questions on social motivation, which assessed how truly or not, their significant others thought they should comply with those malaria preventive measures. This section had response options on a six-point Likert scale thus: 'very untrue', 'mostly untrue', 'untrue', 'true', 'mostly true', and 'very true', which were scored 1, 2, $3,4,5$, and 6 respectively. The total maximum obtainable motivation score was 64 points, while the minimum obtainable score was 12 points.

\section{Section C}

This section assessed participants' levels of behavioural skills. It had a total of seven items and two sub-sections. The first sub-section had three items which assessed how hard or easy it was to comply with ITN and IPTp. Responses to this section were on a four-point Likert scale, thus: 'very hard', 'hard', 'easy', and 'very easy', which were scored 1, 2, 3, and 4 respectively. The second sub-section which assessed the level of effectiveness with which the participants could execute certain tasks relating to ITN use, 
had four items. This section had responses on a four-point Likert scale too, thus: 'very ineffectively', 'ineffectively', 'effectively' and 'very effectively', which were scored 1, 2, 3, and 4 respectively. The total maximum obtainable behavioural skills score was 28 points, while the minimum obtainable score was 7 points.

\section{Section $D$}

This section assessed their frequency of ITN use during pregnancy, that is, the number of days in a week in which they slept under an ITN. Frequency of ITN use was categorized as: Never, Seldom (once to twice weekly), Sometimes (thrice to 4 times a week), Often (5-6 times a week) and Almost always. These categories were scored as: $1,2,3,4$ and 5 respectively. This section also asked whether or not they had received any IPT, and the number of doses they had received.

\section{Ethics approval and consent to participate}

Ethical approval was obtained to carry out the research, from the Ethics Committee for Research Involving Human Subjects of the Universiti Putra Malaysia (UPM) (UPM/TNCPI/ RMC/1.4.18.2 (JKEUPM). Permission was also obtained from the Ethics Committee of the State Specialist Hospital, Maiduguri (SSH/GEN/64/Vol.1). All the respondents were first taken through the respondent's information sheet in Hausa language, after which informed verbal consent was obtained from them. This was due to the low literacy rates in the study location [18], and it had been approved by the JKEUPM.

\section{Questionnaire testing}

This was done in stages thus: content validity by experts, face validity by 20 pregnant women, test of construct validity by on different pregnant women, and finally test of reliability by 63 out of the 190 initial respondents.

\section{Content validity}

Content validity was assessed using an expert group [19] who went through the questionnaire to ensure that the wordings of its items were clear, and that they represent their content domain. The assessment team comprised of three Public Health specialists and an Obstetrics and Gynaecology specialist.

\section{Face validity}

Twenty antenatal care attendees were conveniently selected from a secondary-level health centre in Maiduguri, northeastern Nigeria, to assess the questionnaire. The criteria for selection was to be a fluent Hausa speaker, and also be at their first antenatal visit for their index pregnancy. The questionnaires were administered to them by interviewers, following which they were asked to assess each section of the questionnaire, based on order of its questions, language clarity, and whether the questions under each construct appropriately measured the respective constructs. Order of questions was scored as Good order, Average order, or Poor order; language clarity was scored as Clear, Average or Confusing; while appropriateness of construct measurement was scored as Good, Average, or Poor.

\section{Construct validity and reliability}

A further cross-sectional study was conducted at the same antenatal clinic, a week after the face-validity study. A hundred and ninety respondents were conveniently selected using the same criteria as for face validity. They were similarly made to complete the questionnaire, and the data obtained was then analysed in IBM SPSS version 22. Internal consistency was measured using the Cronbach's alpha. The motivation and behavioural skills constructs of the questionnaire were subjected to an exploratory factor analysis (EFA) to determine how properly the items of each of their respective sub-sections correctly fitted. The assumptions for conducting an EFA had been met, as the data for these two constructs were collected on an interval scale, and there were also positive correlations between all the items. Items with factor loadings less than 0.3 were suppressed, and for the rotation, the oblique method (promax) was chosen due to some high correlations among some items.

Two weeks after the first questionnaire administration, it was re-administered to 63, out of the 190 respondents. These 63 respondents were randomly selected from the complete list of the initial 190 respondents using the random function in Microsoft Excel 2013. The Cohen's kappa was measured to determine the reliability between the answers at first and second administration, for items of the information section, since the responses were in a nominal form. For the motivation, behavioural skills and frequency of ITN use sections, the Krippendorffs alpha were measured to determine reliability.

\section{Results}

The results of face validity by the 20 respondents are presented in Table 1 . For the information section, $85 \%$ rated the order of its questions as good, 95\% rated its language clarity as clear, while $75 \%$ rated its appropriateness for its construct as good. For the motivation section, $75 \%$ rated the order of its questions as good, while $80 \%$ rated its language clarity as clear, and its appropriateness for its construct as good. For behavioural skills, $80 \%$ rated the order of its questions as good, $85 \%$ rated its language clarity as clear, while $80 \%$ rated its appropriateness for its construct as good. All other ratings given were average, with none of the ratings given as poor.

For the subsequent questionnaire evaluation, the ages of the 190 respondents ranged from 17 to 45 years, with mean (SD) of 25.4 (5.5) years. Most of them were married in a monogamous setting (75.3\%), around a third had some form of employment (32.1\%), while $84.2 \%$ were multigravidae (Table 2). 
Table 1 Face validity results $(N=20)$

KNOWLEDGE
Order of questions
Good order
Average
Poor order
Total
Language clarity
Clear
Average
Confusing
Total
Appropriately measures level of knowledge
Good
Average
Poor
Total

\section{MOTIVATION}

Order of questions
Good order
Average
Poor order
Total
Language clarity
Clear
Average
Confusing
Total

Appropriately measures level of motivation

Good
Average
Poor
Total

BEHAVIOURAL SKILLS

Order of questions

$$
\begin{aligned}
& \text { Good order } \\
& \text { Average } \\
& \text { Poor order } \\
& \text { Total } \\
& \text { Language clarity } \\
& \text { Clear } \\
& \text { Average } \\
& \text { Confusing } \\
& \text { Total }
\end{aligned}
$$

Appropriately measures level of behavioural skills

$$
\begin{aligned}
& \text { Good } \\
& \text { Average } \\
& \text { Poor }
\end{aligned}
$$$$
\text { Total }
$$

Freq. (\%)

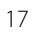

3

0

20

Freq. (\%)

19

1

0

20

Freq. (\%)

15

5

0

20

Freq. (\%)

15

5

0

20

Freq. (\%)

16

4

0

20

Freq. (\%)

16

4

0

20

Freq. (\%)

16

4

0

20

Freq. (\%)

17

3

0

20

Freq. (\%)

16

4

0

20

Table 2 Respondents' characteristics $(N=190)$

\begin{tabular}{lll}
\hline Factor & Frequency $(\mathrm{n})$ & Percentage $(\%)$ \\
\hline Age &
\end{tabular}

$\begin{array}{lll}<20 \text { years } & 25 & 13.2 \\ \geq 20 \text { years } & 165 & 86.8 \\ \text { Total } & 190 & 100.0\end{array}$

Ethnicity

Kanuri

$60 \quad 31.6$

(95)

(5)

$(00)$

(100)

Marghi

(75) Fulani

(25) Others

(00) Total

$46 \quad 24.2$

Hausa

24.2

$19-10.0$

$16 \quad 8.4$

$12 \quad 6.3$

$14 \quad 7.4$

23

190

12.1

\section{Family type}

Monogamy

143

8.4

6.3

7.4

Polygamy

47

100.0

Total

190

75.3

(75)

Education

(00)

(100)

None

38.9

Primary

16.8

Secondary

32.1

Tertiary

12.1

Total

100.0

Occupation status

(100)

\section{Employed}

Not employed

Total

24.7

100.0

(80)

(20)

(00)

\section{Type of residence}

(100)

Permanent resident
Internally displaced
Total

Total

Gravidity

Primgravida

Multigravida

Grandmultigravida

61

$\begin{array}{ll}155 & 81.6 \\ 35 & 18.4 \\ 190 & 100.0\end{array}$

(85)

The Cronbach's alpha results for these sections ranged from 0.773 to 0.889 as presented in Table 3. For motivation, enough items were predicted by each factor, as evidenced by Kaiser-Meyer-Olkin (KMO) of 0.840 . The variables were correlated enough, as evidenced by a significant Bartlett's test of Sphericity $(<0.001)$. Rotation sum of square factor loadings indicated that $69 \%$ of the total variance was being explained by the three significant factors. For behavioural skills, enough items were 
Table 3 Summary of Cronbach's alpha results $(N=190)$

\begin{tabular}{lll}
\hline Section & No. of items & Cronbach's alpha \\
\hline Knowledge & 46 & 0.859 \\
Motivation I (Question 1 to 8) & 8 & 0.872 \\
Motivation II (Question 9 to 12) & 4 & 0.889 \\
Behavioural skills & 7 & 0.773 \\
\hline
\end{tabular}

Table 4 Factor loadings based on factor analysis for the motivation construct (all items retained)

\begin{tabular}{|c|c|c|c|c|}
\hline & \multirow[t]{2}{*}{ Item summary } & \multicolumn{3}{|l|}{ Subscale } \\
\hline & & Goodness & Trueness & Pleasantness \\
\hline a. & $\begin{array}{l}\text { Don Allah a gaya mana } \\
\text { yaya kyaun ko rashin kyaun } \\
\text { wadannan game da lafiyarki }\end{array}$ & & & \\
\hline Mot1 & $\begin{array}{l}\text { Rinka kwana a cikin gidan } \\
\text { sauro mai feshin magani }\end{array}$ & 0.542 & & 0.370 \\
\hline Mot2 & $\begin{array}{l}\text { Rinka kwana akai-akai fiye } \\
\text { da da a cikin gidan sauro } \\
\text { mai feshin magani }\end{array}$ & 0.555 & & \\
\hline Mot3 & $\begin{array}{l}\text { Rinka shan maganin kariya } \\
\text { daga cutar malariya da aka } \\
\text { ba ni yayin goyon ciki }\end{array}$ & 0.889 & & \\
\hline Mot4 & $\begin{array}{l}\text { Rinka shan dukkan } \\
\text { magungunan kariya daga cutar } \\
\text { malariya da aka bani ko da ina } \\
\text { jin lafiyata kalau }\end{array}$ & 0.912 & & \\
\hline b. & $\begin{array}{l}\text { Don Allah a gaya mana } \\
\text { yaya dadi ko rashin dadin } \\
\text { wadannan halayen a gareki }\end{array}$ & & & \\
\hline Mot5 & $\begin{array}{l}\text { Rinka kwana a cikin gidan } \\
\text { sauro mai feshin magani }\end{array}$ & & & 0.912 \\
\hline Mot6 & $\begin{array}{l}\text { Rinka kwana akai-akai fiye } \\
\text { da da a cikin gidan sauro } \\
\text { mai feshin magani }\end{array}$ & & & 0.932 \\
\hline Mot7 & $\begin{array}{l}\text { Rinka shan maganin kariya } \\
\text { daga cutar malariya da aka } \\
\text { ba ni yayin goyon ciki }\end{array}$ & 0.441 & & 0.397 \\
\hline Mot8 & $\begin{array}{l}\text { Rinka shan dukkan } \\
\text { magungunan kariya daga cutar } \\
\text { malariya da aka bani ko da ina } \\
\text { jin lafiyata kalau }\end{array}$ & 0.569 & & \\
\hline c. & $\begin{array}{l}\text { Mutanen da ke da } \\
\text { muhimmanci a gare ni suna } \\
\text { tsammanin yakamata in ... }\end{array}$ & & & \\
\hline Mot9 & $\begin{array}{l}\text { Rinka kwana a cikin gidan } \\
\text { sauro mai feshin magani }\end{array}$ & & 0.760 & \\
\hline Mot10 & $\begin{array}{l}\text { Rinka kwana akai-akai fiye } \\
\text { da da a cikin gidan sauro } \\
\text { mai feshin magani }\end{array}$ & & 0.821 & \\
\hline Mot11 & $\begin{array}{l}\text { Rinka shan maganin kariya } \\
\text { daga cutar malariya da aka } \\
\text { ba ni yayin goyon ciki }\end{array}$ & & 0.953 & \\
\hline Mot12 & $\begin{array}{l}\text { Rinka shan maganin kariya } \\
\text { daga cutar malariya da aka } \\
\text { bani ko da ina jin lafiyata kalau }\end{array}$ & & 0.870 & \\
\hline
\end{tabular}

also predicted by each factor, as evidenced by KMO of 0.785. The Bartlett's test of Sphericity was also significant $(<0.001)$. Rotation sum of square factor loadings indicate that $60 \%$ of the total variance was being explained by the two significant factors.

The initial factor loadings for the factor analysis of motivation are presented in Table 4. The motivation construct was able to delineate its items into three main categories, however Mot7 and Mot8 were not able to gauge level of pleasantness, but rather had high factor loadings for level of goodness. Mot1 also had moderate factor loading for level of pleasantness. Since both level

Table 5 Factor loadings based on factor analysis for the motivation construct (two items deleted)

\begin{tabular}{|c|c|c|c|c|}
\hline & \multirow[t]{2}{*}{ Item summary } & \multicolumn{3}{|l|}{ Subscale } \\
\hline & & Goodness & Trueness & Pleasantness \\
\hline a. & $\begin{array}{l}\text { Don Allah a gaya mana } \\
\text { yaya kyaun ko rashin } \\
\text { kyaun wadannan game } \\
\text { da lafiyarki }\end{array}$ & & & \\
\hline Mot1 & $\begin{array}{l}\text { Rinka kwana a cikin gidan } \\
\text { sauro mai feshin magani }\end{array}$ & 0.640 & & 0.354 \\
\hline Mot2 & $\begin{array}{l}\text { Rinka kwana akai-akai fiye } \\
\text { da da a cikin gidan sauro } \\
\text { mai feshin magani }\end{array}$ & 0.651 & & \\
\hline Mot3 & $\begin{array}{l}\text { Rinka shan maganin kariya } \\
\text { daga cutar malariya da aka } \\
\text { ba ni yayin goyon ciki }\end{array}$ & 0.897 & & \\
\hline Mot4 & $\begin{array}{l}\text { Rinka shan dukkan } \\
\text { magungunan kariya daga } \\
\text { cutar malariya da aka bani } \\
\text { ko da ina jin lafiyata kalau }\end{array}$ & 0.878 & & \\
\hline b. & $\begin{array}{l}\text { Don Allah a gaya mana } \\
\text { yaya dadi ko rashin dadin } \\
\text { wadannan halayen a } \\
\text { gareki }\end{array}$ & & & \\
\hline Mot5 & $\begin{array}{l}\text { Rinka kwana a cikin gidan } \\
\text { sauro mai feshin magani }\end{array}$ & & & 0.904 \\
\hline Mot6 & $\begin{array}{l}\text { Rinka kwana akai-akai fiye } \\
\text { da da a cikin gidan sauro } \\
\text { mai feshin magani }\end{array}$ & & & 0.936 \\
\hline c. & $\begin{array}{l}\text { Mutanen da ke da } \\
\text { muhimmanci a gare } \\
\text { ni suna tsammanin } \\
\text { yakamata in ... }\end{array}$ & & & \\
\hline Mot9 & $\begin{array}{l}\text { Rinka kwana a cikin gidan } \\
\text { sauro mai feshin magani }\end{array}$ & & 0.734 & \\
\hline Mot10 & $\begin{array}{l}\text { Rinka kwana akai-akai fiye } \\
\text { da da a cikin gidan sauro } \\
\text { mai feshin magani }\end{array}$ & & 0.794 & \\
\hline Mot11 & $\begin{array}{l}\text { Rinka shan maganin kariya } \\
\text { daga cutar malariya da aka } \\
\text { ba ni yayin goyon ciki }\end{array}$ & & 0.965 & \\
\hline Mot12 & $\begin{array}{l}\text { Rinka shan maganin kariya } \\
\text { daga cutar malariya da aka } \\
\text { bani ko da ina jin lafiyata } \\
\text { kalau }\end{array}$ & & 0.880 & \\
\hline
\end{tabular}


of goodness and level of pleasantness were measuring personal motivation, the two items (Mot7 and Mot8) were dropped, since items with the same wordings appeared in the 'level of goodness section' (Mot3 and Mot4). The final factor loadings after the two items were dropped is presented in Table 5. There was still some moderate cross loading for Mot1, although this was a litthe less than the values in the initial analysis when Mot7 and Mot8 were included. The behavioural skills construct was able to delineate its items into two main categories with no significant cross loading of items (Table 6).

Table 7 presents the socio-demographic characteristics of the retest sample $(N=63)$ and the remaining sample $(N=127)$. Both groups were similar on all factors except employment status, for which the remaining sample had a higher proportion of unemployed persons compared to the retest group $\left(\chi^{2}=3.939, d f=1, p=0.049\right)$.

The Cohen's kappa reliability test for 'Info6' was 0.382 , while those of the other items of the information section ranged from 0.689 to 0.974 as shown in Table 8. The Krippendorff's alpha values for the items of the motivation section ranged from 0.941 to 0.996 , while that for the behavioural skills section ranged from 0.810 to 0.953 (Table 9). For frequency of ITN use, it was 0.988.

\section{Discussion}

The results of the face validity assessment suggests that the questionnaire was comprehensible and acceptable. It also had an acceptable internal consistency, as all the

Table 6 Factor loadings based on factor analysis for the behavioural skills construct

\begin{tabular}{|c|c|c|c|}
\hline & \multirow[t]{2}{*}{ Item summary } & \multicolumn{2}{|l|}{ Subscale } \\
\hline & & Easiness & $\overline{\text { Effectiveness }}$ \\
\hline a. & $\begin{array}{l}\text { A halin yanzu yaya wahalar } \\
\text { ko saukin yadda zaki iya .... }\end{array}$ & & \\
\hline BSkills1 & $\begin{array}{l}\text { Kwana a cikin gidan sauro mai } \\
\text { feshin magani kowace rana? }\end{array}$ & & 0.610 \\
\hline BSkills2 & $\begin{array}{l}\text { Shanye dukkan maganin kariya } \\
\text { daga zazzabin cizon sauro } \\
\text { lokacin goyon ciki? }\end{array}$ & & 0.847 \\
\hline BSkills3 & $\begin{array}{l}\text { Shanye dukkan maganin kariya } \\
\text { daga zazzabin cizon sauro ko } \\
\text { da kikan ji ba dadi? }\end{array}$ & & 0.756 \\
\hline b. & $\begin{array}{l}\text { A halin yanzu yaya kwarewa } \\
\text { ko rashin kwarewarki wajan ... . }\end{array}$ & & \\
\hline BSkills4 & Rataya gidan sauro daidai? & 0.699 & \\
\hline BSkills5 & $\begin{array}{l}\text { Dubawa ko gyara huji da yagewar } \\
\text { gidan sauro mai feshin magani? }\end{array}$ & 0.779 & \\
\hline BSkills6 & $\begin{array}{l}\text { Kara adadin kwanaki a sati da kike } \\
\text { kwana a cikin gidan sauro a halin } \\
\text { yanzu? }\end{array}$ & 0.678 & \\
\hline BSkills7 & $\begin{array}{l}\text { Shawo kan wasu don su goyi bayan } \\
\text { kwana da kike a cikin gidan sauro? }\end{array}$ & 0.884 & \\
\hline
\end{tabular}

Table 7 Comparison of socio-demographic characteristics of test and re-test samples

\begin{tabular}{|c|c|c|c|c|c|c|c|}
\hline \multirow[t]{2}{*}{ Variables } & \multicolumn{4}{|c|}{ Group } & \multirow[t]{2}{*}{$x^{2}$} & \multirow[t]{2}{*}{$d f$} & \multirow[t]{2}{*}{$p$} \\
\hline & \multicolumn{2}{|c|}{$\begin{array}{l}\text { Test sample } \\
\text { Freq. (\%) } \\
\mathrm{n}=127\end{array}$} & \multicolumn{2}{|c|}{$\begin{array}{l}\text { Retest sample } \\
\text { Freq. (\%) } \\
n=63\end{array}$} & & & \\
\hline Less than 20 & 14 & $(11.0)$ & 9 & $(14.3)$ & & & \\
\hline 20 years and above & 113 & $(89.0)$ & 54 & $(85.7)$ & & & \\
\hline Ethnicity & & & & & 2.707 & 6 & 0.845 \\
\hline Kanuri & 41 & $(32.3)$ & 20 & $(31.7)$ & & & \\
\hline Hausa & 30 & $(23.6)$ & 18 & $(28.6)$ & & & \\
\hline Babur & 13 & $(10.2)$ & 4 & $(6.3)$ & & & \\
\hline Shuwa & 10 & $(7.9)$ & 6 & $(9.5)$ & & & \\
\hline Marghi & 9 & $(7.1)$ & 2 & $(3.2)$ & & & \\
\hline Fulani & 9 & $(7.1)$ & 6 & $(9.5)$ & & & \\
\hline Others & 15 & 11.8) & 7 & $(11.1)$ & & & \\
\hline Family type & & & & & 0.852 & 1 & 0.356 \\
\hline Monogamy & 93 & $(73.2)$ & 50 & $(79.4)$ & & & \\
\hline Polygamy & 34 & $(26.8)$ & 13 & $(20.6)$ & & & \\
\hline Type of residence & & & & & 0.407 & 1 & 0.523 \\
\hline Permanent resident & 102 & $(80.3)$ & 53 & $(84.1)$ & & & \\
\hline IDP & 25 & $(19.7)$ & 10 & $(15.9)$ & & & \\
\hline Education level & & & & & 1.295 & 3 & 0.730 \\
\hline None & 52 & $(40.9)$ & 21 & (33.3) & & & \\
\hline Primary & 20 & $(15.7)$ & 11 & $(17.5)$ & & & \\
\hline Secondary & 38 & $(29.9)$ & 23 & $(36.5)$ & & & \\
\hline Tertiary & 17 & $(13.4)$ & 8 & $(12.7)$ & & & \\
\hline Occupational status & & & & & 3.939 & 1 & 0.049 \\
\hline Not employed & 92 & $(72.4)$ & 36 & $(58.1)$ & & & \\
\hline Employed & 35 & $(27.6)$ & 26 & $(41.9)$ & & & \\
\hline Type of residence & & & & & 0.407 & 1 & 0.523 \\
\hline Permanent resident & 102 & $(80.3)$ & 53 & $(84.1)$ & & & \\
\hline IDP & 25 & $(19.7)$ & 10 & (15.9) & & & \\
\hline Gravidity & & & & & 0.767 & 2 & 0.681 \\
\hline Primgravida & 18 & $(14.2)$ & 12 & $(19.0)$ & & & \\
\hline Multigravida & 63 & $(49.6)$ & 30 & $(47.6)$ & & & \\
\hline Grandmultigravida & 46 & $(36.2)$ & 21 & $(33.3)$ & & & \\
\hline
\end{tabular}

Cronbach's alpha values were within the acceptable range of 0.70 to 0.95 [20]. It also demonstrated a good reliability, with all the items of the information section having a Cohen's kappa of greater 0.60 [21], except for one item, which was fever (zazzabi). However, fever being a cardinal feature of malaria, was still retained in the questionnaire, due to its relevance, but re-worded to a simpler terminology, 'hotness of the body' (zafin jiki). The Krippendorff's alpha values for motivation, behavioural skills and ITN use were all above 0.8 , and as such, 
Table 8 Summary of test retest results for knowledge

\begin{tabular}{|c|c|c|}
\hline$\overline{\mathrm{SNO}}$ & Item & $\begin{array}{l}\text { Cohen's } \\
\text { kappa }\end{array}$ \\
\hline & Ta yaya ake kamuwa da malariya? & \\
\hline Info1 & Cizon sauro & $\begin{array}{l}\text { (no } \\
\text { variance) }\end{array}$ \\
\hline Info2 & Jikewa da ruwan sama & 0.803 \\
\hline Info3 & Sauyin yanayi & 0.858 \\
\hline Info4 & Cin wasu irin abinci & 0.974 \\
\hline \multirow[t]{2}{*}{ Info5 } & Aikin wahala a rana & 0.817 \\
\hline & Mene ne alamun cutar malariya? & \\
\hline Info6 & Zazzabi later reworded to Zafin jiki & 0.382 \\
\hline Info7 & Karkarwa & 0.705 \\
\hline Info8 & Ciwon kai & 0.821 \\
\hline Info9 & Ciwon gabobi & 0.740 \\
\hline Info10 & Rashin son cin abinci & 0.826 \\
\hline Info11 & Jin bani da lafiya & 0.850 \\
\hline Info12 & Dacin baki & 0.806 \\
\hline Info13 & Jin amai & 0.689 \\
\hline Info14 & Yin amai & 0.858 \\
\hline Info15 & Jin kamar lafiya ta kalau & 0.868 \\
\hline Info16 & $\begin{array}{l}\text { Shin sauron da ke yada cutar malariya na iya cizo } \\
\text { da rana? }\end{array}$ & 0.862 \\
\hline Info17 & $\begin{array}{l}\text { Shin goyon ciki na iya kara kawo kamuwa da cutar } \\
\text { malariya? }\end{array}$ & 0.877 \\
\hline Info18 & Shin cutar malariya na iya cutar da mai goyon ciki? & 0.859 \\
\hline \multirow[t]{2}{*}{ Info19 } & Shin cutar malariya na iya cutar da dan tayin ciki? & 0.858 \\
\hline & $\begin{array}{l}\text { Wace irin illa malariya kan iya jawowa lokacin } \\
\text { goyon ciki? }\end{array}$ & \\
\hline
\end{tabular}

Info20 Tana iya sa mace mai ciki ta rasa isasshen jinni $\quad 0.875$

Info21 Yin bari 0.850

Info22 Haihuwa ba lokacin da ya dace ba $\quad 0.900$

Info23 Haddasa haihuwar da/'ya mai karancin nauyi $\quad 0.865$

Info24 Mutuwar uwa 0.839

Info25 Mutuwar dan tayi 0.841

Info26 Kina da masaniyar gidan sauron da ke dauke $\quad 0.945$

da feshin maganin sauro?

Me ake yi da gidan sauron da ke dauke da feshin maganin sauro?

Info27 Kawar da sauro

Info28 Kawar da beraye

Info29 Gidan sauro mai feshin magani ya fi wanda ba feshin magani

Info30 Feshin maganin gidan sauron kan iya zamowa hadari gare ni muddin na kwanta a cikinsa

Bayan tsawon wane lokaci ya kamata a wanke gidan sauro mai feshin magani?

Info31 Bayan wata 1

Info32 Bayan wata 3

0.903

Info33 Bayan wata 6
Table 8 Summary of test retest results for knowledge (Continued)

\begin{tabular}{|c|c|c|}
\hline SNo & Item & $\begin{array}{l}\text { Cohen's } \\
\text { kappa }\end{array}$ \\
\hline & $\begin{array}{l}\text { Da me ya kamata a wanke gidan sauro } \\
\text { mai feshin maganin sauro? }\end{array}$ & \\
\hline Info34 & Ruwa da sabulu & 0.890 \\
\hline \multirow[t]{2}{*}{$\operatorname{lnfo} 35$} & Ruwa da omo & 0.818 \\
\hline & $\begin{array}{l}\text { A ina ya kamata a shanya gidan sauro mai } \\
\text { feshin magani? }\end{array}$ & \\
\hline $\operatorname{lnfo36}$ & A inuwa & 0.844 \\
\hline Info37 & A rana & 0.885 \\
\hline \multirow[t]{2}{*}{$\operatorname{lnfo38}$} & $\begin{array}{l}\text { Kina da masaniya akan maganin da ake bayarwa } \\
\text { na kariya lokacin goyon ciki? }\end{array}$ & 0.913 \\
\hline & $\begin{array}{l}\text { Wane irin magani ake bayarwa don kariya daga } \\
\text { cutar malariya lokacin goyon ciki? }\end{array}$ & \\
\hline Info39 & Chloroquine & 0.927 \\
\hline \multirow[t]{2}{*}{$\operatorname{lnf} 40$} & Fansidar & 0.921 \\
\hline & $\begin{array}{l}\text { Nawa ne adadin kwayoyin maganin kariya daga } \\
\text { cutar malariya da ake bayarwa kowane lokaci } \\
\text { ga mai goyon ciki? }\end{array}$ & \\
\hline $\operatorname{lnfo} 41$ & Kwaya 2 & 0.923 \\
\hline Info42 & Kwaya 3 & 0.923 \\
\hline $\operatorname{lnfo} 43$ & Kwaya 4 & 0.925 \\
\hline \multirow[t]{2}{*}{$\operatorname{lnfo} 44$} & $\begin{array}{l}\text { Maganin da ake ba wa masu goyon ciki don kariya } \\
\text { daga cutar malariya zai }\end{array}$ & \\
\hline & iya zama mai illa akan cikin da nake goyo & 0.925 \\
\hline Info45 & $\begin{array}{l}\text { Ana iya shan maganin kariya daga cutar malariya } \\
\text { ba tare da an ci abinci ba? }\end{array}$ & 0.915 \\
\hline
\end{tabular}

acceptable [22]. Considering that Mot7 and Mot8 did not have even moderate loadings for level of pleasantness, it was reasonable to expunge them since they had high cross loadings with level of goodness, for which items with similar wordings (Mot3 and Mot4) in its category had higher factor loadings (Table 4).

Table 9 Results of test retest reliability for motivation and behavioural skills

\begin{tabular}{llll}
\hline Item & Krippendorff's alpha & Item & Krippendorf's alpha \\
\hline Mot1 & 0.981 & BSkills1 & 0.896 \\
Mot 2 & 0.965 & BSkills2 & 0.886 \\
Mot3 & 0.946 & BSkills3 & 0.947 \\
Mot4 & 0.964 & BSkills4 & 0.890 \\
Mot5 & 0.996 & BSkills5 & 0.953 \\
Mot6 & 0.981 & BSkills6 & 0.810 \\
Mot9 & 0.972 & BSkills7 & 0.915 \\
Mot10 & 0.942 & & \\
Mot11 & 0.953 & & \\
Mot12 & 0.941 & & \\
\hline
\end{tabular}


Among the limitations of this study was the inadequate sample size to allow for a confirmatory factor analysis, and this should be considered in future studies.

\section{Conclusion}

The Hausa language IMB questionnaire on malaria in pregnancy demonstrated good validity, and a high level of reliability. It is as such recommended for use among Hausa speaking communities to ensure uniformity and objectivity. It could also be translated, validated, and adapted in other malaria endemic regions. Further reliability tests like the item-response theory models should be performed to determine item difficulty and item discrimination.

\section{Supplementary information}

Supplementary information accompanies this paper at https://doi.org/10. 1186/s12889-020-08513-y.

\section{Additional file 1. \\ Additional file 2. \\ Additional file 3.}

\section{Abbreviations}

EFA: Exploratory factor analysis; ITN: Insecticide-treated net; IPTp: Intermittent preventive treatment in pregnancy; IMB: Information-motivation-behavioural skills; KMO: Kaiser-Meyer-Olkin; WHO: World Health Organization

\section{Acknowledgements}

The authors acknowledge and wish to express their appreciation to the women who participated in this study. They also thank the enumerators and all ante-natal care staff of the State Specialist Hospital, Maiduguri, for their tremendous support.

\section{Authors' contributions}

$A B$ and $S S$ conceived the study. AB, SS, NZ, BN and BA participated in the study design and manuscript review. $\mathrm{AB}$ and $\mathrm{SS}$ did the data analysis and manuscript writing. All authors read and approved the final manuscript.

\section{Funding}

No external funding was received for this study.

\section{Availability of data and materials}

The data set, questionnaire, and consent forms for this study are available as supplementary material. To maintain respondents' anonymity, only two indirect identifiers were retained (age and employment status).

\section{Ethics approval and consent to participate}

Ethical approval was obtained to carry out the research, from the Ethics Committee for Research Involving Human Subjects of the Universiti Putra Malaysia (UPM) (UPM/TNCPI/RMC/1.4.18.2 (JKEUPM). Permission was also obtained from the Ethics Committee of the State Specialist Hospital, Maiduguri (SSH/GEN/64/Nol.1). All the respondents were first taken through the respondent's information sheet in Hausa language, after which informed verbal consent was obtained from them. This was due to the low literacy rates in the study location, and it had been approved by the JKEUPM.

\section{Consent for publication}

Not Applicable.

\section{Competing interests}

The authors declare that they have no competing interests.

\section{Author details}

'Department of Disease Control and Elimination, Medical Research Council

The Gambia at London School of Hygiene and Tropical Medicine, Fajara, The
Gambia. ${ }^{2}$ Department of Community Health, Faculty of Medicine and Health Sciences, Universiti Putra Malaysia, Selangor Darul Ehsan, Malaysia. ${ }^{3}$ Unit of Biostatistics and Research Methodology, Universiti Sains Malaysia, Kelantan, Malaysia. ${ }^{4}$ Department of Obstetrics and Gynaecology, University of Maiduguri, Maiduguri, Nigeria.

Received: 25 June 2019 Accepted: 11 March 2020

Published online: 24 March 2020

\section{References}

1. WHO. World malaria report 2016. Geneva: World Health Organization; 2017.

2. FMOH. Strategic Plan 2009-2013: A Road Map for Malaria Control in Nigeria. Abuja; Federal Ministry of Health; 2008.

3. WHO. A strategic framework for malaria prevention and control during pregnancy in the African region. Geneva: World Health Organization; 2004.

4. NPC. Nigeria Demographic and Health Survey 2013. Abuja: National Population Commission; 2014.

5. Iliyasu Z, Gajida AU, Galadanci HS, Abubakar IS, Baba AS, Jibo AM, Aliyu MH. Adherence to intermittent preventive treatment for malaria in pregnancy in urban Kano, northern Nigeria. Path Glob Heal. 2012;106:323-9.

6. Akaba GO, Otubu JAM, Agida ET, Onafowokan O. Knowledge and utilization of malaria preventive measures among pregnant women at a tertiary Hospital in Nigeria's Federal Capital Territory. Niger J Clin Pract. 2013;16:201-6.

7. Bawa JA, Auta T, Liadi S. Prevalence of malaria : knowledge, attitude and cultural practices of pregnant women in Katsina. Eur Sci J. 2014;10:148-67.

8. Ibrahim SM, Umar NI, Garba NA, Isa B, Usman HA, Bako BG. Utilization of insecticide treated nets among pregnant women attending antenatal clinic in a suburban referral hospital, north-East Nigeria. Br J Med Med Res. 2014;4: 2343-51.

9. Singh R, Musa J, Singh S, Ebere UV. Knowledge, attitude and practices on malaria among the rural communities in Aliero, northern Nigeria. J Fam Med Prim Care. 2014;3:39-44.

10. Teryila KR, Haruna HK, Kasamu D, Dathini H. Knowledge and practice of plasmodiasis prevention among pregnant women in Maiduguri, Borno State. West Afr J Nurs. 2014;25:52.

11. Kallamu H, Abdul Rahman H, Hayati KS, Ismaila UG. Association between knowledge, attitude and preventive practices on malaria among pregnant women with and without malaria attending ante-Natal Care in Zamfara State, Nigeria. Int J Public Heal Clin Sci. 2015;2:68-78.

12. ECOWAS - SWAC/OECD: The Atlas on Regional Integration. www.atlaswestafrica.org. Accessed $07 \mathrm{Jul} 2018$.

13. Munro S, Lewin S, Swart T, Volmink J. A review of health behaviour theories: how useful are these for developing interventions to promote long-term medication adherence for TB and HIV/AIDS? BMC Pub Heal. 2007;7:1-16.

14. Fisher J, Fisher W. Changing AIDS risk behavior. Psych Bull. 1992;111:455-74.

15. Adebayo AM, Akinyemi OO, Cadmus EO. Knowledge of malaria prevention among pregnant women and female caregivers of under-five children in rural Southwest Nigeria. Peer J. 2015;3:e792.

16. Osborn CY, Amico KR, Fisher WA, Egede LE, Fisher JD. An informationmotivation-behavioral skills analysis of diet and exercise behavior in Puerto Ricans with diabetes. J Health Psychol. 2010;15:1201-13.

17. WHO: Process of translation and adaptation of instruments. http://www.who. int/substance_abuse/research_tools/translation/en/. Accessed 24 Jul 2016.

18. NBS. The national literacy survey. Abuja: National Bureau of Statistics; 2010 .

19. Saw SM, Ng TP. The design and assessment of questionnaires in clinical research. Sing Med J. 2001;42:131-5.

20. Tavakol M, Dennick R. Making sense of Cronbach's alpha. Int J Med Educ. 2011;2:53-5.

21. McHugh ML. Interrater reliability: the kappa statistic. Biochemia Med. 2012; 22:276-82.

22. Krippendorff K. Content analysis: an introduction to its methodology. California: Sage Publications; 2005.

\section{Publisher's Note}

Springer Nature remains neutral with regard to jurisdictional claims in published maps and institutional affiliations. 